Economic Intelligence Branch of the Ministry of Agriculture and Fisheries, and as member of that staff gained special experience of inquiries in the field of agricultural statisties and economics. He specialized in the study of agricultural development as affected by the course of international trade, commercial policy and political conditions. In 1939 he joined the Food (Defence Plans) Department, which on the outbreak of war became the Ministry of Food, where he was associated with numerous inquiries of an economic character, and continued with that Ministry until the early part of 1945. Although Mr. Nash has not had any personal associations with the agricultural industry, he has combined a wide experience of inquiries into the economics of agriculture, food supplies and prices, with previous experience of intraand extra-mural teaching.

\section{Metallurgy in the University of Birmingham}

THE University of Birmingham has received a gift of nearly $£ 137,000$ from constituent associations and members of the British Non-Ferrous Metals Federation. This munificent gift has been made in response to an appeal recently issued for $£ 250,000$ for the development of the Department of Metallurgy. The University intends to expand this Department to meet the need which has been repeatedly expressed by industry for more metallurgists. In addition to studying metallurgical science to the highest attainable level, the science of metallurgical production is being studied and new courses developed, which will be designed to provide industry with men specially qualified to apply new knowledge to industrial processes. In order to facilitate these new studies, a division of the Department has been created to study industrial metallurgy. This will not be regarded as an alternative subject to metallurgical science; courses of study for all students will be identical, at a high scientific level, until a late stage in the honours course, and any specialization will be confined to a relatively small portion of the degree course. Industrial metallurgy will be pursued intensively, principally as a subject for study by graduates in the same way as metallurgical science to-day is most completely dealt with in the universities of Britain. The Department of Metallurgy at Birmingham will be a unified department in which it is hoped to effect for all students an appropriate balance between the scientific and industrial aspects of the subject. Prof. D. Hanson, who has been professor of metallurgy for many years, has now been joined by Prof. L. Aitchison as professor of industrial metallurgy (see Nature, February 23, p. 222). It is hoped that graduates from other universities will take advantage of the new Department of Industrial Metallurgy for the purpose of graduate studies, in which appropriate courses will be arranged.

\section{Science in India}

IN his presidential address, "The Progress of Science in India", to the National Institute of Sciences of India, at the twelfth annual general meeting, held at Bangalore on January 1, Mr. D. N. Wadia referred to the recent announcement by the Education Department of the Government of India on the recognition of the Institute as the premier scientific organisation of the country, and to the Government building grant for $1946-47$ of rupees $2,20,000$ and recurring grant of rupees $1,17,000$ towards the secretariat, national research fellowships, grants-insid for publications, etc. The Council of the Institute has also been entrusted with the administration of the endowment of the four research fellowships in India offered by Imperial Chemical Industries, Ltd., three of which have now been awarded. During the last two years the Institute has received from the Rockefeller Foundation of New York a grant of 15,000 rupees a year, which is being distributed to some twenty-three scientific societies and academies in India in aid of their publications. In view of its new status the Council of the Institute has now accepted responsibility as adviser to the Government on all scientific matters, the co-ordination of the activities of scientific academies, societies and institutions, the distribution of grants-in-aid to scientific publications, from funds provided by the Rockefeller Foundation or the Government, and the administration of funds for the award of research fellowships. At an early date it is expected that the work of the Institute will assume more and more the character of a national research council. A Provisional Research Grants Committee has already been established, and the Council proposes to take up immediately the constitution of the new research committees.

Reviewing the work of the Board of Scientific and Industrial Research, under which more than one hundred and twenty-five research schemes are at present in operation, Mr. Wadia refers to an increase in the Government allocation to the finances of the Board, the vote for the current year being estimated at rupees $30,00,000$. The scientific work of the Board is carried out through some twenty research commit. tees and he mentions in particular the work of the Metals Committee, the Electro-Chemical Industries Committee, the Fuel Research Committee, the Heavy Chemicals Committee, the Plastics Committee, Glass and Refractories Committee, the Dyestuffs Committee, and the Radio Research Committee. An offspring of the activities of the Board was the institution of the Industrial Research Planning Committee under Sir R. K. Shanmugham Chetty in December 1943, which presented a report early in 1945, recommending the organisation of a national research council for India. Mr. Wadia concluded his address with an outline of the salient features of the memorandum on the development of agriculture and animal husbandry in India by Sir P. M. Kharegat, commonly known as the Kharegat Plan, published by the Imperial Council for Agricultural Research.

\section{Prehistory of Ceylon}

THE early archæology of Ceylon is of considerable interest, but is as yet not well understood. $\mathrm{Mr}$. P. E. P. Deraniyagala, director of museums, Ceylon, has devoted much time and thought to the matter ; in Spolia Zeylanica (vol. 24, Part 2) he presents Part 2 of "Some Aspects of the Prehistory of Ceylon". It is to be regretted that it has not been found possible to employ a com. petent draughtsman who understands the technique of drawing stone implements, for the two photographs are well-nigh useless and the drawings little better; photographs of stone implements are seldom very helpful, but it is not impossible to produce first-class drawings. Several pages of the article are devoted to a proposed new typology of the artefacts. A description of the industrial finds of the Ratnapura and Balangoda culture phases, using the new typology, follows, and there is also a brief note on some cave paintings found at Mandagalgé. In conclusion, there is given a useful if tentative table of correlations and a bibliography. 